\title{
The antecedents of Muslim
} customers' intention to invest in

\begin{abstract}
Purpose - The purpose of this study is to examine the impacts of product knowledge, perceived quality, perceived risk and perceived value on customers' intention to invest in Islamic Banks. This study specifically examines an Islamic bank's term deposits.

Design/methodology/approach - Structural equation modeling was used to analyze the data collected from 217 customers of an Islamic bank in Indonesia using an online survey.

Findings - This study highlights the central and dual roles of perceived risk as both the independent and the intervening variable that mediates the relationship between product knowledge and Muslim customer intention to invest in an Islamic bank's term deposits.

Research limitations/implications - This study only investigates term deposits as one type of investment in Islamic banks. This study contributes to the literature by examining the role of product knowledge, perceived quality, perceived risk and perceived value on Muslim customer intention to invest in Islamic term deposits.

Practical implications - The results of this study highlight the requirement for Islamic banks to educate customers to improve the depositors' product knowledge because Muslim customers' risk and value perception and intention are strongly influenced by product knowledge.

Originality/value - The investigation of perceived risk is particularly relevant for Islamic financial products because of the inherent nature of risk sharing in Islamic finance. This study investigates the role of product knowledge in influencing the Muslim customers' perception of risk, quality, value and their intention to invest in Islamic bank term deposits. Ideally, the profit loss sharing concept (PLS) should be applied; however, in this context, revenue sharing is applied because of Indonesia's central bank regulation.
\end{abstract}

Keywords Product knowledge, Perceived risk, Islamic bank, Perceived value, Perceived quality

Paper type Research paper

\section{Introduction}

In the current uncertain global economy, investors are looking for low-risk and stable investments. One of the alternatives for such investment is term or time deposits. A time

(C) Sri Rahayu Hijrah Hati, Sigit Sulistiyo Wibowo and Anya Safira. Published by Emerald Publishing Limited. This article is published under the Creative Commons Attribution (CC BY 4.0) licence. Anyone may reproduce, distribute, translate and create derivative works of this article (for both commercial and non-commercial purposes), subject to full attribution to the original publication and authors. The full terms of this licence may be seen at http://creativecommons.org/licences/by/4.0/legalcode

This research was financially supported by the Directorate General of Higher Education, Ministry of National Education, Indonesia (NKB-1755/UN2.R3.1/HKP.05.00/2019).

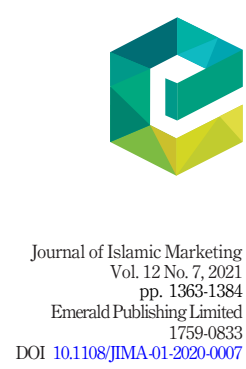


JIMA

12,7

1364

deposit is characterized as an investment with a fixed rate of interest. This is a safe investment because it is resistant to the changing economy and ensures growth in savings (Bankbazaar.com, 2018). The customers' effort to avoid risk by investing in term deposits has driven the deposit market to become a supercompetitive market. In the USA, for example, many banks have increased interest rates to attract more customers' deposits (Gray, 2018). This phenomenon is aligned with the classical, neo-classical and contemporary economic theories, which state that interest rates determine the level of savings in the economy (Haron and Ahmad, 2000).

Similar to conventional banks, Islamic banks rely on depositors' money as a major source of funds (Haron and Ahmad, 2000). However, the concept of interest or fees charged by the lender to the borrower is prohibited in Islam (Haron and Ahmad, 2000). According to Islamic principles, if a Muslim wants to use his money to make more money, then he should be willing to put his money at risk (Hossain, 2009). In other words, risk taking from an Islamic perspective can lead to both profits and losses because philosophically it is only God who can determine future outcomes while Man cannot determine the future path of his action (Rosly and Zaini, 2008).

Therefore, the Islamic customer banks, especially those that invest their money in term deposit products, should be willing to bear risks regardless of the type of contract used in the investment deposits (e.g. mudarabah, commodity murabahah, etc.). In the investment deposit under the mudharabah contract, the depositor or customer, known as rabbul mal, is seeking the investment opportunity and will invest through the bank, known as mudarib, which manages the fund (Hamzah et al., 2014). As a substitute for interest, the Islamic bank applies the revenue sharing and profit loss sharing system. The profit loss sharing system is the most ideal system, which is fully aligned with the Islamic juristic principle in regard to the concept of risk, which is called as "al-ghunm bil ghurm", which means "one is entitled to a gain if one agrees to bear the responsibility for the loss" (Hossain, 2009). Profit is shared based on the pre-determined ratio (e.g. 40:60 or 30:70) based on the bank's performance (Hamzah et al., 2014). However, a revenue sharing contract basically gives more privilege to the customers because the bank should cover all the operating costs for the investment.

Based on the above discussion, the risk factor can be identified as one factor that may influence Muslim customers to feel reluctance to invest in an Islamic bank. However, many other factors that influence customer banking behavior and loyalty, such as product knowledge, perceived quality and perceived value (Bloemer et al., 1998; Devlin, 2002; Dusuki and Abdullah, 2007; Gray, 2018), have been identified. Product knowledge, for example, is found to determine the customer choice criteria for retail banking in the UK (Devlin, 2002). Customers with low product knowledge tend to select retail banking based on geographical proximity and recommendations, while knowledgeable customers tend to select based on the intrinsic attributes of the banking services such as service attributes, rate of return and low fees. Another study in the banking sector reported that customers place high value on sophisticated online tools, national branch networks and other services that can only be provided by large banks (Gray, 2018). Moreover, regardless of the size of the bank, customers place high value on the interest rate on deposits (Gray, 2018).

When we specifically look at Muslim banking behavior, we can see that Muslim customers who invest their money in Islamic banks are still largely driven by the profit motive, which was confirmed by the negative relationship between the Islamic bank's interest-free product and the interest rate of conventional banks (Haron and Ahmad, 2000). A similar pattern of Muslim banking behavior is reported in Sudan, Jordan, Singapore and Malaysia (Haron and Ahmad, 2000). Among the previous mentioned Muslim majority countries, Indonesia is the largest Muslim country in the world, with more than 225 million Muslims, constituting $87.2 \%$ of its population (Livepopulation.com, 2018). Despite 
Indonesia's large Muslim population, however, the market share for the Islamic bank deposits in the country are much lower compared to conventional banks. The total market share for the Islamic bank term deposits in Indonesia as of June 2018 reached only IDR 195.325bn (Indonesia Financial Service Authority, 2018), which is lower than that of the conventional bank, which amounted to IDR 2,084,018bn; thus, the former only amounted to $9.3 \%$ of the conventional bank's term deposits (Bank Indonesia, 2018).

Based on the above discussion, this study aims to examine the Muslim investment behavior related to term deposits. Term deposits were selected because they theoretically involve much higher risk and take longer to mature compares to saving and demand deposits that allow the customer to withdraw the money at any time (Haron and Ahmad, 2000). However, because of the local central bank regulations, profit loss sharing is not applied in the Indonesian Islamic bank term deposit product. As a consequence, the Muslim customers of the Islamic bank are not exposed to the risk of losing their investment. Our study contributes by examining the role of product knowledge in the Muslim customers' risk, quality and value perception and its impact on their intention to invest in Islamic bank's term deposits. The rest of this paper is organized as follows. Section 2 discusses related literature on the determinants of saving and investment. Section 3 describes the methodology used in this study. Section 4 presents the empirical findings and analysis, and the last section provides that conclusion for this study.

\section{Literature review}

\subsection{Deposits in Islamic banks}

In economic literature, the concept of saving is closely related to consumption. Two main theories in examining saving and consumption behavior are the permanent income hypothesis (Friedman, 1957) and the life-cycle hypothesis (Ando and Modigliani, 1963). The permanent income hypothesis divides income into two components: permanent and transitory. The expected income over a long time period is defined as permanent income, while the difference between permanent and actual income is defined as transitory income. The permanent income hypothesis argues that saving is primarily determined by permanent income, while transitory changes in income do not have any impact on saving. The life cycle hypothesis suggests that individual consumption is spread over one's lifetime. Thus, one accumulates savings over the working period, and then uses those savings to maintain the consumption level during the retirement period. This hypothesis suggests that demographic factors play an important role in determining savings, and these theories emphasize the role of interest rates toward saving.

In Islamic finance, interest rates are considered as gharar and riba, which are prohibited in any economic transactions. Gharar (literally misrepresentation or fraud) exists when there is deception in trading such as misrepresentation about quality, pricing and product types (Warde, 2000). Riba (literally an increase) can be defined as the act of charging rent for the use of money (Warde, 2000). Riba has a closer meaning to interest than gharar. However, in the contemporary finance system, both are embedded in many transactions; therefore, interest rates are essentially prohibited in Islamic finance.

Islam prohibits interest rates, because their use would inhibit the attainment of Maqasid al-Shariah. Maqasid al-Shariah is the higher objective of the rules of Islamic law to safeguard Muslims' faith (din), self (nafs), intellect (aql), posterity (nasl) and wealth (mal) to realize well-being (falah) and a fulfilling life (hayat tayyibah) (Chapra et al., 2008; Meera and Larbani, 2006). Maqasid al-Shariah reflects the holistic view of Islam to facilitate the normal functioning of society by enhancing the public good (maslaha) and avoiding actions that cause harm to individuals and society ("Maqasid al-Shari'ah", 2020). 
JIMA 12,7

However, despite Maqasid al-Shariah's ideal concept and objectives, it is not easy for Muslims to realize the concept in every aspect of life, including in the context of Islamic banking and finance (Dusuki and Abozaid, 2007). Note that interest rates still may play important roles in many Muslim countries, particularly in monetary and banking systems.

The existing literature shows that the relationship between interest rates and savings in Muslim countries is mixed. Kasri and Kassim (2009) studied the determinants of savings in Islamic banks in Indonesia from 2000 to 2007 using macroeconomic data. They reported that the interest rate has important roles in determining the level of saving in the Islamic banks. Moreover, they reported that depositors in Islamic banks tend to transfer their savings to conventional banks when the rate of returns of Islamic financial products is lower than that of interest rates.

Akram and Akram (2015) analyzed the savings behavior in four countries with Muslim majority populations and four countries with non-Muslim majority populations using data from 1975 and 2012. They found that the relationship between the interest rate and savings is only significant for the non-Muslim majority countries. Because they use macroeconomic variables, they cannot show the role of religiosity in determining savings in the Muslim majority countries. Furthermore, they suggest using micro-level data to investigate this relationship. A recent study by Mushtaq and Siddiqui (2016) using data from 23 non-Muslim and 23 Muslim countries from 1999 to 2014 shows that interest rates do not have any impact on bank deposits. Furthermore, they reported that although some people in Muslim-majority countries put their money in conventional banks, their savings are not sensitive to changes in interest rates. This means that the motive for putting money in the bank is for saving or precautionary purposes. Similar to Akram and Akram (2015), they suggest looking for different variables at the micro level.

Dusuki and Abdullah (2007) surveyed 750 respondents in different regions in Malaysia to examine the reasons why people engage with Islamic banks in a dual banking environment. They found that the determinants are a combination of Islamic and financial reputation and quality service; however, this study does not focus on the determinants of saving. Overall, the prior studies mainly examine the determinants of saving at a macro level. Conversely, our study contributes by examining the determinants of saving at a micro level.

\subsection{Saving behavior in Indonesia as a Muslim majority country}

Indonesia has the largest Muslim population in the world (Diamant, 2019). The total number of Muslim adherents in the country in 2020 is estimated to be 229 million or around $87.2 \%$ of its total population ("Muslim Population By Country", 2020). However, although Indonesia has the largest Muslim population, the development of the Islamic bank in the country has been very slow (Pramono, 2018). After the establishment of the Islamic bank in Indonesia in 1991, the market share of the bank has experienced the so-called "five per cent trap" because the bank's market share never exceeded 5\% of the total market share for almost 25 years (Bloomberg, 2019). The market share of the Islamic bank saving products represented a low percentage of IDR, amounting to 394.7tn (6.8\%) of IDR and a total market share of 5,799.8tn (Jayani, 2019). In addition to the low market share, previous studies examining the level of knowledge and awareness about Islamic banks in multiple countries, such as Malaysia, Indonesia, UAE, Pakistan and Saudi Arabia, show that Indonesia only ranked in the fourth position in term of Islamic finance knowledge after Malaysia, UK and Pakistan. The low market share and lack of knowledge of the Muslim population of the country about Islamic finance and banking raises the question of why this situation exists in Indonesia as a Muslim majority country. Thus, the study aims to examine the impact of knowledge on Muslim customers' intention to save or invest in Islamic banks. 


\subsection{Product knowledge}

Erol and El-Bdour (1989) reported that religion is not the main reason for Islamic bank customers to patron Islamic bank. Knowledge of the Islamic bank's products plays an important role in selecting financial products along with the bank's reputation and image (Haron et al., 1994). A study among Muslim customers in Malaysia shows that a majority of Muslim consumers have very limited knowledge about Islamic banks (Ahmad and Haron, 2002). The Muslim consumers do not even really know the philosophical objectives of the Islamic bank. What they do know is that interest is prohibited in Islam (Ahmad and Haron, 2002). A majority of them have no specific knowledge about certain terminology of the Islamic bank (e.g. mudarabah, ijarah, istisna, etc.) (Ahmad and Haron, 2002).

From the conventional literature, product knowledge comprises expertise and familiarity with products (Alba and Hutchinson, 1987). Familiarity refers to the accumulation of productrelated experiences, while expertise reflects the ability of the consumer to effectively perform product-related tasks (Rao and Monroe, 1988). Moreover, product knowledge can be classified into objective and subjective knowledge (Rao and Monroe, 1988). Objective knowledge is information that is stored in the memory of the consumer, while subjective knowledge is what the consumer perceives they know about the product (Rao and Monroe, 1988). Previous knowledge about the product supports the acquisition of new knowledge and the utilization of existing knowledge (Park and Lessig, 1981). One study in an automobile industry reported that consumers' perception of product quality is influenced by the knowledge of the consumer (Blair and Innis, 1996). Eisingerich and Bell (2008) also suggested that customer education that improves customer knowledge will influence the way the consumer perceives service quality. A study conducted by Haron et al. (1994) reported that Muslim and non-Muslim customers have similar perceptions when selecting bank services such as in terms of the quality of service and the provision of fast service. Thus:

\section{H1. Product knowledge has a positive impact on perceived quality.}

Products comprise visible and invisible characteristics (Ophuis and Van Trijp, 1995). According to prospect theory, decision-makers compare both the expected value and the expected risk related to the decision (Wang and Hazen, 2016). The inability of a product to present visible or physical cues will make the customer perceive the product as risky (Laroche et al., 2003). A study in the fashion industry shows that customers who cannot evaluate the tangibility of products feel insecure about the item's ability to perform (Aghekyan-Simonian et al., 2012). This insecure feeling because of the unavailability of physical cues makes customers feel afraid of financial loss as a result of purchasing uncertain products or services (Grewal et al., 1994). A company that is able to provide important information about its products and services may help customers to develop product knowledge and thus reduce the consumer's uncertainty about certain products (Eisingerich and Bell, 2008). Consumer knowledge will increase perceived value and help the customers to develop a more trusting relationship with the service provider because the knowledgeable consumer has a better opportunity to process the information in greater depth (Eisingerich and Bell, 2008).

In the context of Islamic banks, product knowledge is highly important because the products of conventional and Islamic banks have some basic differences. The consumer should know that, in Islam, the benefit of the society is prioritized. Therefore, interest rates are prohibited because they only benefit one party's interest. As an alternative, a profit-sharing scheme is offered to consider the society's interest as a whole (Hilman, 2016). A term deposit in an Islamic bank is an investment deposit under the principles of Mudharabah where the customer and the bank are both known as partners (Amin, 2013; Haron et al., 1994). With term 
JIMA

12,7

deposits, the customers will not get a predetermined return for a fixed period and do not carry any guarantee of their nominal value because they would with a conventional bank. However, depositors are informed in advance about the formula of the profit-sharing ratio used for sharing the net earnings of the investment pool with the bank, which are heavily dependent on the bank's performance (Amin, 2013). Thus, the depositors will share both the profit and the loss that the bank may incur. The longer the maturity of investment, the higher the weightage of the profit-sharing agreement. Many previous studies have shown that, on an average, the Islamic investment rates are significantly lower than the conventional bank (Chong and Liu, 2009). However, note that, in practice, the sharing of Islamic banking returns in Indonesia is performed using the revenue sharing concept rather than the profit and loss sharing (PLS) concept (Ismal, 2012). Thus, the investors are free from the obligation to bear any risk. In other words, they most likely always receive a positive and regular return (Ismal, 2012). However, without any product knowledge about the characteristics of the term deposit in an Islamic bank, the customer will perceive that the risk of investing in an Islamic bank is higher compared to the risk of investing in a conventional bank. Therefore,

\section{H2. Product knowledge has a negative impact on perceived risk.}

Product value refers to the consumer's overall assessment of the utility of a product (or service) based on perceptions of what is received and what is given (Zeithaml, 1988). One study that examined consumer perceptions of remanufactured automobiles shows that perceived value is significantly influenced by consumer knowledge (Wang and Hazen, 2016). A previous study on Islamic banks shows that Muslim customers in both rural and urban areas in Malaysia in general have a lack of awareness in terms of the existence of Islamic banks, Islamic banking terms and attributes of Islamic banking (Thambiah et al., 2010). Thus, they remain unaware about the value of the Islamic bank products, their relative advantages and the compatibility of the products with conventional bank products (Thambiah et al., 2010). Therefore:

\section{H3. Product knowledge has a positive impact on perceived value.}

The effect of product knowledge on purchase intention have been largely examined in the new and foreign product context (Bamber et al., 2012; Lin and Chen, 2006; Wang et al., 2013). Scholars had suggested various strategies such as educating the market at an early stage through a promotion program for school-age children and teenagers; emotionally attractive advertising; Islamic banking and finance education and tactical field personal selling, to educate Muslim consumers to increase the Islamic bank penetration rate (Setyobudi et al., 2015). A previous study reported that consumers with higher product knowledge would have a higher understanding and appreciation of new products (Wang et al., 2008), which in turn would generate higher purchase intention; in other words, expert consumers would have a higher intention to purchase compare to novice consumers (Cakici and Shukla, 2017). In the Islamic bank research context, Muslim customers in Malaysia consider to patronize the Islamic banks if they have a comprehensive understanding about the operation of such banks (Haron et al., 1994). Therefore:

H4. Product knowledge has a positive impact on intention to invest.

\subsection{Perceived quality and perceived value}

A study by Mylonakis et al. (1998) concluded that the perceived quality of products and services is one of the main criteria for customers in selecting a bank. Perceived quality is among the primary components of perceived value (Dodds and Monroe, 1985; Ruiz et al., 2008). It is a vital element to investigate in the formation of perceived value because it contributes to the 
company's competitive advantage (Reichheld and Sasser, 1990) and is considered the most difficult element for competitors to imitate (Parasuraman and Grewal, 2000). Using tourism data, Chiang and Lee (2013) show that perceived value is a dynamic determinant of tourism selection. This is also a key factor to understand purchase behavior, which is related to the improvement of service quality; therefore, the following hypothesis was formulated:

H5. Perceived quality has a positive impact on perceived value.

\subsection{Perceived quality and perceived risk}

Snoj et al. (2004) found that perceived quality and perceived risk have a strong relationship. Research by Clow et al. (1998) found that cues of service quality can contribute to reducing the perceived risk of consumers. These cues can be in the form of any stimuli that can deliver information about the quality of the product or service before the consumer can consume or experience it (Mehrotra and Palmer, 1985). Especially now that customers are more sensitive to the financial aspects of products and services, it is increasingly important to study this relationship.

In the context of banking, financial risk becomes the main risk that a consumer focuses on because the main products offered by banks are financial products (Chen and Chang, 2005) such as savings and term deposits. However, perceived risk can be observed more broadly to not only include financial loss but also discrepancies with regard to expected utility, physical damage, unhappiness and negative social image (Chen and Chang, 2005). Snoj et al. (2004) found that perceived quality has a weaker impact when it is measured alone but a stronger impact when perceived risk is included. This negative link between perceived quality and perceived risk was reported by Sweeney et al. (1999). Thus, the following hypothesis can be formulated:

H6. Perceived quality has a negative impact on perceived risk.

\subsection{Perceived risk and perceived value}

Islam has its own juristic principle in regard to the concept of risk. The Arabic phrase "al-ghunm bil ghurm" means "one is entitled to a gain if one agrees to bear the responsibility for the loss" (Hossain, 2009). Based on this concept, Echchabi and Olaniyi (2012) identified risk sharing as one of the implications of the brotherhood and cooperation principle in Islamic banking, which distinguishes it from its conventional counterparts. In the Islamic banking system, cooperation and sharing must happen between the provider of the funds and the user (Ahmad, 2016; Iqbal and Molyneux, 2005). In the conventional business context, Snoj et al. (2004) reported that perceived risk has a negative influence on perceived value. In a study by Kwun and Oh (2004) in a restaurant context, perceived risk was reported to have a negative impact on perceived value both before and after dining in the restaurant. In their study, perceived risk was a more important consideration for customers compared to brand or price factors.

Based on the discussion above, the following hypothesis was formulated:

H7. Perceived risk has a negative impact on perceived value.

\subsection{Perceived quality and intention}

Perceived quality in the service industry is known as service quality. A study by Ali et al. (2013) described perceived service quality as the customer perception of the actual 
JIMA

12,7

1370

performance of the service received by the customer and provided by the company, including in the Islamic banking context. The study also found that the quality of service is directly influenced by the customer's perceptions of performance levels. In the tourism industry, perceived quality of a destination's offerings was found to lead to behavioral intentions of tourists to visit the destination (Žabkar et al., 2010). In a study of coffee shops, both perceived product quality and perceived service quality had positive influences on the intention to revisit the coffee shops (Ting et al., 2018).

In the context of Islamic financial products, Newaz et al. (2016) studied the relationship between religiosity, buying attitude and purchase intention. They found that purchasing attitude has full mediation for Islamic financial products, except for Islamic insurance products. Therefore, the next hypothesis is:

H8. Perceived quality has a positive impact on intention to invest in term deposits.

\subsection{Perceived risk and intention}

Intention to invest is a type of purchasing behavior intention. Customers are expected to gain positive consequences from a product to make them feel satisfied or engage in purchasing behavior. However, when customers face the potential for negative consequences from using a product, we call this perceived risk. Negative consequences result in a negative impact for customers and decrease their purchase intention (Stone and Grønhaug, 1993).

Research by Croy et al. (2010) found that the intention to save is greater in a more (vs less) risk-tolerant person. Therefore, customers who are less likely to hold risky financial asset will lower their intention to save or invest in a bank. This study also found that risk-taking is positively associated with income, is negatively associated with age and is lower in women than in men. Thus, the following hypothesis can be formulated:

H9. Perceived risk has a negative impact on customers' intention to invest in term deposits.

\subsection{Perceived value and intention}

Perceived value refers to a customer's evaluation of the quality received. Perceived value is one of the more intangible determinants of a bank's strategy. Perceived value and image have been related to the loyalty of the consumer in the banking sector (Roig et al., 2006). Kuo et al. (2009) reported that perceived value has a positive impact on both customer satisfaction and intention. Higher perceived value leads to higher purchase intention. Accordingly, the subsequent hypothesis can be formulated:

H10. Perceived value has a positive impact on customers' intention to invest in term deposits.

The ten research hypotheses are summarised in Figure 1 below.

\section{Method}

This research is quantitative with a single cross-sectional design. The design is aimed to capture the current condition of customers of Islamic banks regarding their willingness to save in the form of term deposits. An online questionnaire was used as a method of data collection, which was distributed through personal connections and social media. This method of data collection was chosen because of its ease of use, flexibility and the ability to reach a diverse pool of respondents (Epstein et al., 2001). Convenience sampling was used to gather as many respondents as possible in a limited time frame. There was no prerequisite 


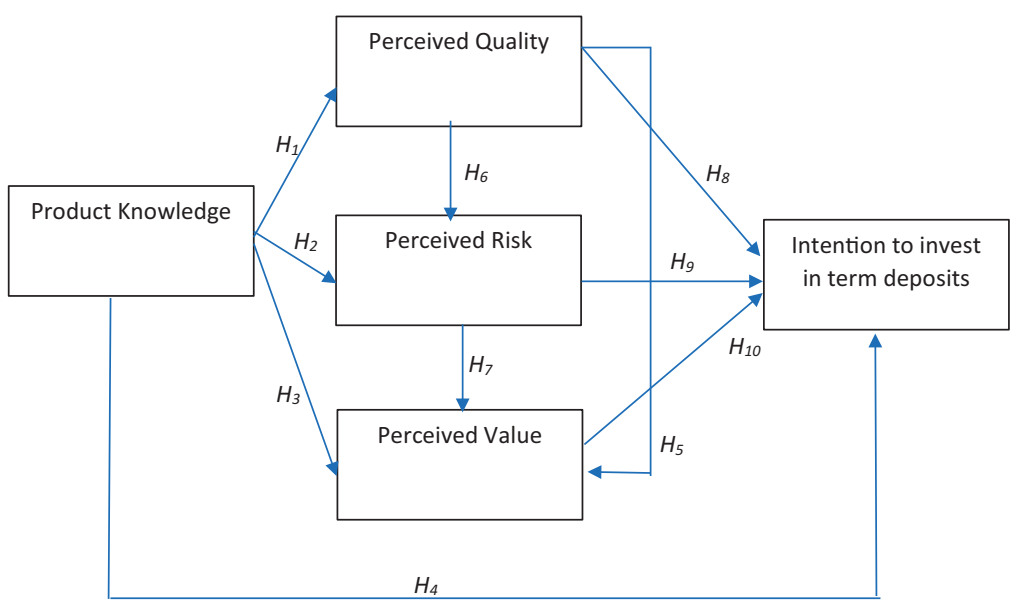

Muslim majority country

1371

Figure 1. Research model

for the respondents to have already been a customer of Islamic banks because the variables in this study are based on perceptions and not customer experience. However, the respondents were required to answer one filtering question on whether they had ever opened a term-deposit account in either a conventional or an Islamic bank.

In this study, there are five variables of interest, namely, product knowledge, perceived quality, perceived risk, perceived value and intention to save. Each variable was measured using modified items from the established questionnaire from the previous literature. Modifications were required as the study specifically investigates consumer knowledge, perception and intention in Islamic term deposit products (Table 1). The measure of product knowledge was modified from an instrument of product knowledge and comprises seven items (Nepomuceno et al., 2014). The measure of perceived quality was modified from a perceived quality scale instrument and comprises three items (Das, 2015; Wang, 2017). Perceived risk was measured using a modified financial risk instrument, which comprises three items (Agarwal and Teas, 2001). The researchers modified the perceived value scale from a previous study conducted in the banking services context, comprising three items (Roig et al., 2006). Intention to invest in an Islamic bank term-deposit was adapted from an intention to use Islamic personal loan scale, which comprises five items (Amin et al., 2011).

The questionnaire was translated to the Indonesian language to ensure that the respondents would completely understand the items. The items used were operationalized using a seven-point Likert scale ranging from "highly disagree" to "highly agree". The tests of validity and reliability were performed before proceeding to the primary test. The SEM results indicate that the questionnaire items used are valid and reliable because the composite reliability (CR) values are above 0.7 and the average variance extracted (AVE) values are above 0.5 (Bacon et al., 1995; Hair et al., 2017).

A total of 217 responses were obtained. Respondent characteristics are presented in Table 2. A majority of the respondents were married (48.8\%), had bachelor's degrees (38.7\%), had an income between IDR 1 and $24.9 \mathrm{~m}(78.34 \%)$, were female (58.1\%) and had both conventional and Sharia accounts (52.5\%). An interesting point here is that not all Muslim consumers in this study own accounts in an Islamic bank, which is in line with the statistics that show that Islamic financial product uptake is still low. 


\begin{tabular}{lll} 
Variable & Items & Adapted sources \\
\hline
\end{tabular}

Product 1. I am knowledgeable about Islamic bank term deposits

Nepomuceno et al. knowledge

2. The information search I have performed on Islamic bank term deposits is strong

3. I do not have much experience with Islamic bank term deposits (reversed)

1372

4. In general, I have good knowledge about Islamic bank term deposits

5. I am well informed about Islamic bank term deposits

6. Compared to my friends and acquaintances, I am knowledgeable about Islamic bank term deposits

7. Compared to experts in this area, I have good knowledge about Islamic bank term deposits

Perceived quality 1 . The Islamic bank term deposit product is superior compared to other investment products

(2014b)

2. The Islamic bank offers a term deposit product with excellent features

3. The overall Islamic bank term deposit quality is good

Perceived risk 1. Considering the potential investment involved, opening a term deposit account in this Islamic bank would not be risky

2. I think that opening a term deposit account in the Islamic bank would lead to financial risk (reversed)

3. Given the potential expenses associated with the opening of the term deposit account in the Islamic bank, the overall risk is very substantial

Perceived value 1 . The payment of profit sharing is fully justified

2. The return of the Islamic bank term deposit is good for the expense it costs

3. The total cost is reasonable

Intention to 1. I am interested in opening an Islamic bank term deposit account

invest in Islamic 2. I am interested in opening an Islamic bank term deposit account

Wang (2017), Das

(2015)

Agarwal and

Teas (2001)

Table 1.

bank term

in the future

deposits

3. I will open an Islamic bank term deposit account someday

4. I would like to open an Islamic bank term deposit account

5. I will definitely recommend Islamic bank term deposits to others

\section{Analysis}

Before the researcher conducted the hypotheses testing using structural equation modeling, an ANOVA was conducted to examine whether there were any significant differences based on the respondent account ownership, which was classified into three types: conventional account only, Sharia account only and mixed account.

Based on Figure 2, the conventional only account holder had the lower product knowledge $($ mean $=2.9189)$, followed by the mixed account holder $($ mean $=3.9225)$. The Sharia only account holder had the highest product knowledge (mean $=4.0283$ ) (Figure 3).

In term of perceived quality, there are no significant differences found in term of perceived quality among the different account holders. The mixed account holders have the highest perception of the perceived quality of the Islamic term deposits (mean $=4.4930$ ), followed by Sharia only account holders (mean $=4.4424)$ and conventional only account holders $($ mean $=4.2200)$. The higher perceived product quality of the Islamic banks gives a 


\begin{tabular}{|c|c|c|c|c|}
\hline Variable & Category & Frequency & $(\%)$ & $\begin{array}{l}\text { Muslim } \\
\text { maiority }\end{array}$ \\
\hline Marital status & $\begin{array}{l}\text { Single } \\
\text { Married } \\
\text { Widow/Widower }\end{array}$ & $\begin{array}{r}104 \\
106 \\
7\end{array}$ & $\begin{array}{r}47.9 \\
48.8 \\
3.3\end{array}$ & country \\
\hline Education & $\begin{array}{l}<\text { Diploma } \\
\text { Bachelor's degree } \\
\text { Master's degree } \\
\text { Doctoral degree }\end{array}$ & $\begin{array}{l}69 \\
84 \\
47 \\
17\end{array}$ & $\begin{array}{r}31.7 \\
38.7 \\
21.7 \\
7.8\end{array}$ & 1373 \\
\hline Family income & $\begin{array}{l}1-24.9 \mathrm{~m} \\
25-49.9 \mathrm{~m} \\
50-74.9 \mathrm{~m} \\
75-100 \mathrm{~m} \\
>100 \mathrm{~m}\end{array}$ & $\begin{array}{r}170 \\
25 \\
14 \\
6 \\
2\end{array}$ & $\begin{array}{l}78.34 \\
11.5 \\
6.5 \\
2.8 \\
0.9\end{array}$ & \\
\hline Gender & $\begin{array}{l}\text { Male } \\
\text { Female }\end{array}$ & $\begin{array}{r}91 \\
126\end{array}$ & $\begin{array}{l}41.9 \\
58.1\end{array}$ & \\
\hline Account ownership & $\begin{array}{l}\text { Conventional only } \\
\text { Sharia only } \\
\text { Mixed } \\
\text { Total }\end{array}$ & $\begin{array}{r}70 \\
33 \\
114 \\
217\end{array}$ & $\begin{array}{r}32.3 \\
15.2 \\
52.5 \\
100.0\end{array}$ & $\begin{array}{r}\text { Table } 2 . \\
\text { Demographic profile }\end{array}$ \\
\hline
\end{tabular}

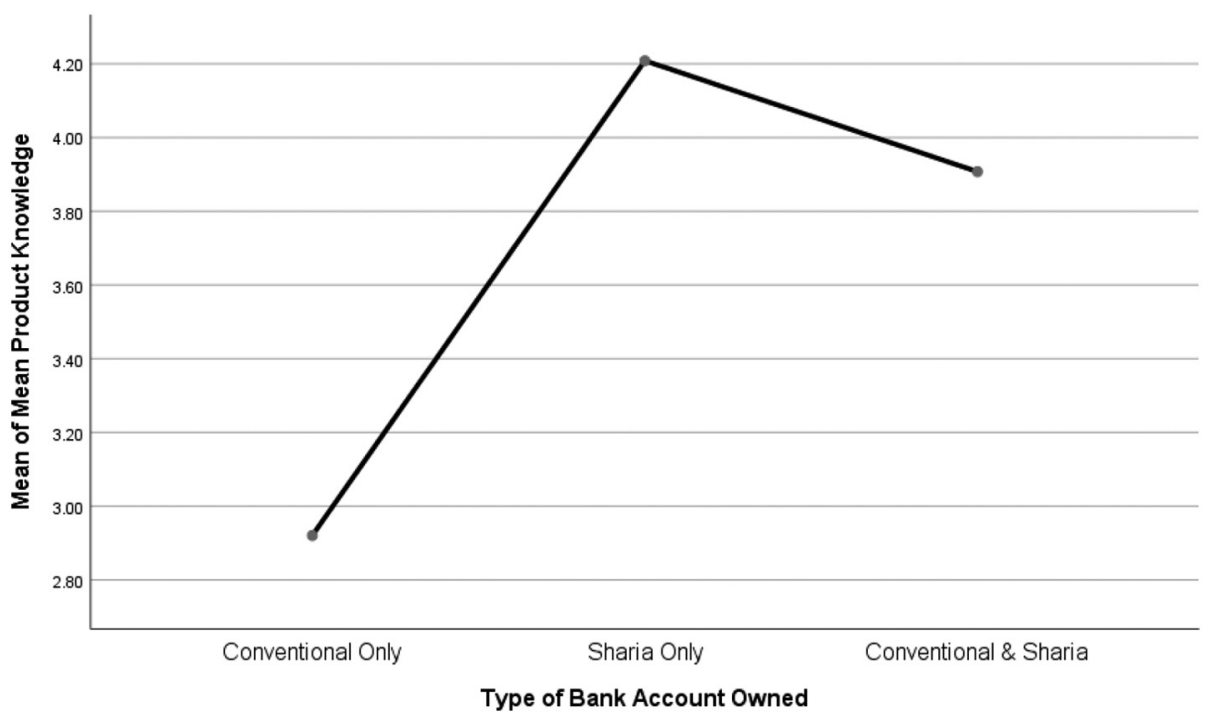

Figure 2.

Product knowledge based on type of bank account

positive signal to the Islamic banks because the mixed account owners' perception must be based on the objective comparison between the conventional and Islamic banks' perceived quality (Figure 4).

In term of perceived risk, the conventional only account holders perceived the Islamic term deposit as high in risk (mean $=4.0929$ ). However, Sharia only account holders had the lowest risk perception (mean $=3.7424$ ). The mixed account holder group had moderate risk 
JIMA

12,7

1374

Figure 3.

Perceived quality based on type of bank account

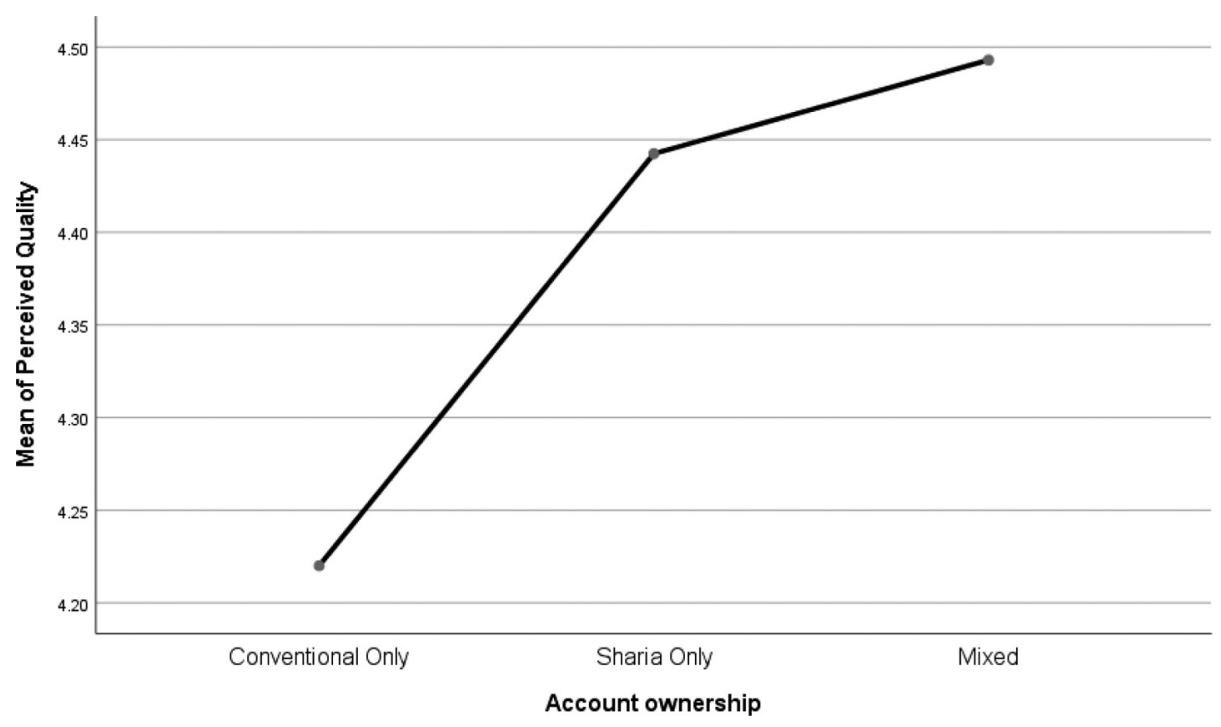

Figure 4.

Perceived risk based on type of bank account

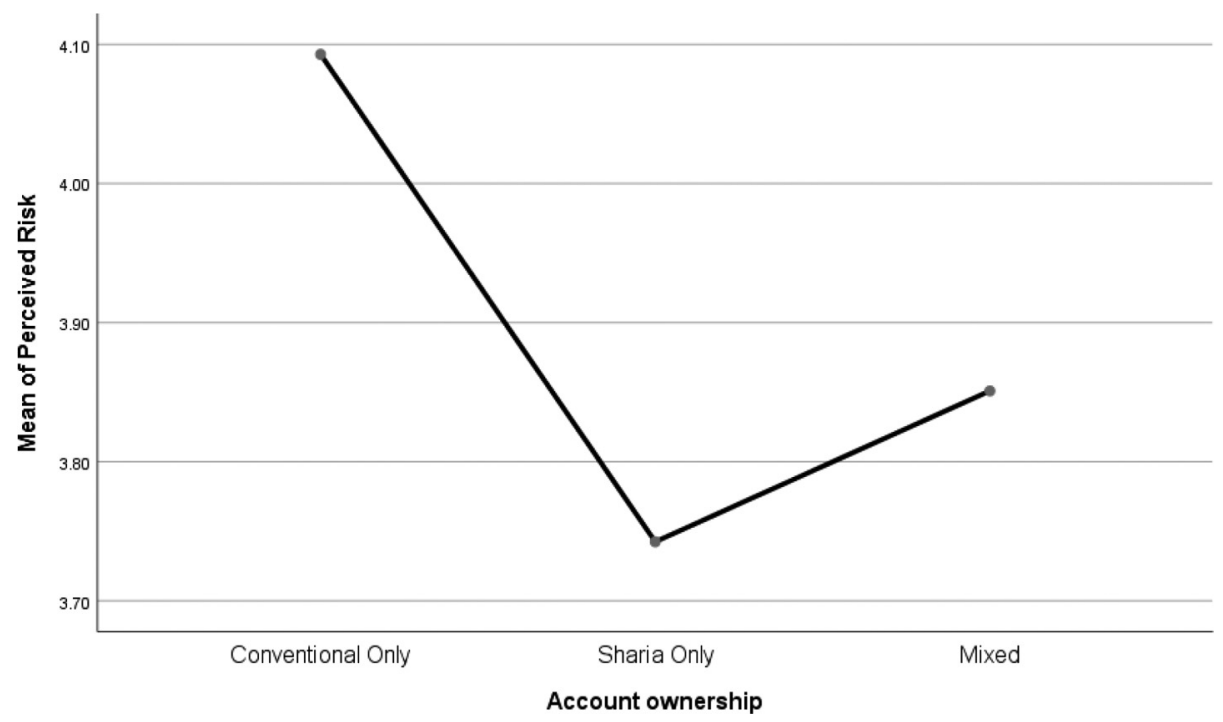

perception regarding the Islamic bank term deposit (mean $=3.8509$ ). The low risk perception about the Islamic bank term deposit products by Sharia only account holders may indicate that they have higher product knowledge regarding the revenue sharing concept attached to the product, indicating that they are aware that there is no risk of loss in the term deposit investment.

As shown in Figure 5, Sharia only account holders have the highest perceived value (mean $=4.3175)$, followed by the mixed account holders (mean $=4.3175)$. The lowest perceived value is found among conventional-only account holders (mean $=4.0314$ ). 
Based on Figure 6, we can see that the highest intention to invest in the Islamic bank term deposit was significantly influenced by the current type of account owned by the respondent. Mixed account holders had the highest intention to invest in Islamic bank term deposit (mean $=4.4509)$, followed by Sharia only (mean $=4.3939)$ and conventional only account holders (mean $=4.0171$ ).

In short, as shown in Table 3, the significant differences between the three types of account holders (conventional only, Sharia only and mixed) lie in product knowledge, perceived value and intention to invest.

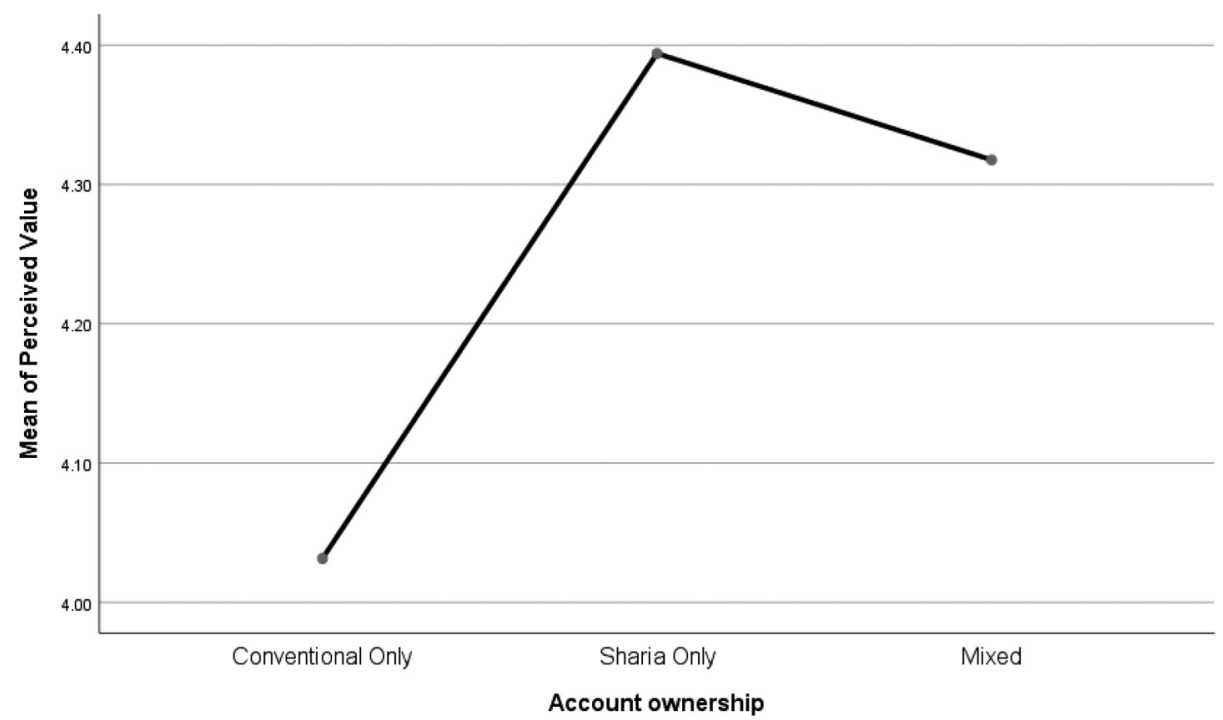

Figure 5.

Perceived value based on type of bank account

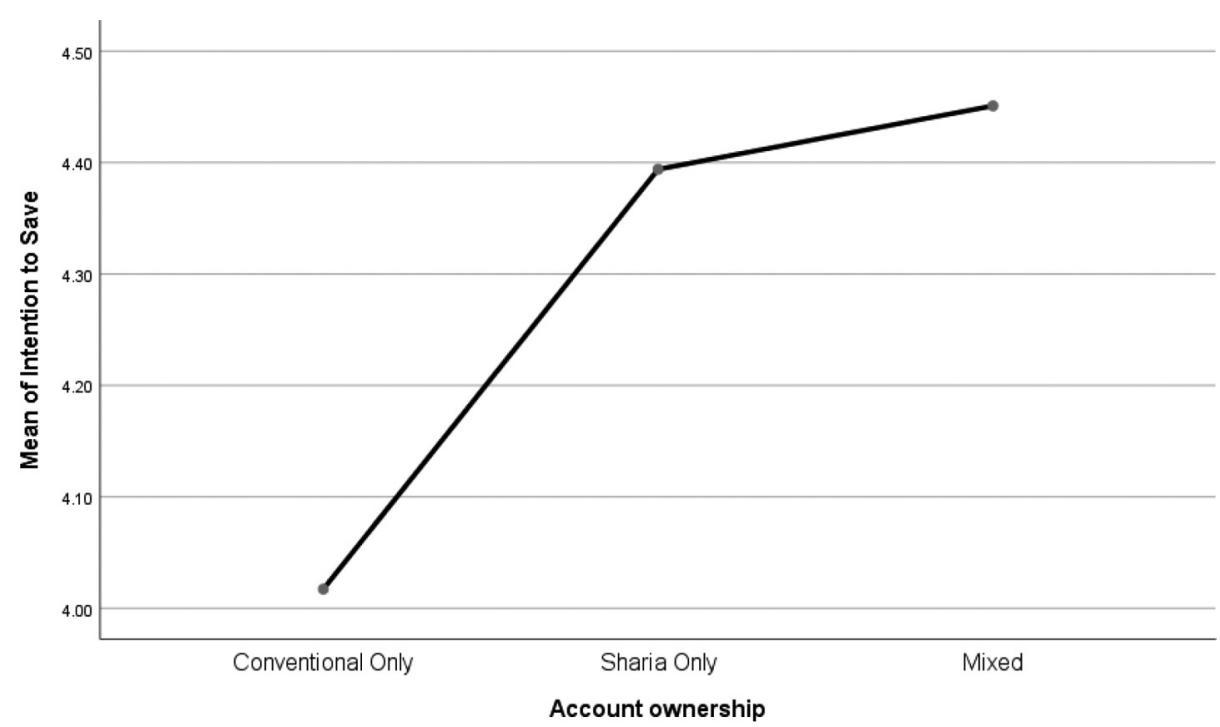

Figure 6. Intention to invest based on type of bank account 
JIMA

12,7

\section{6}

Table 3.

ANOVA

Hypothesis testing was done using structural equation modeling with LISREL 8.51 (See Table 3). To ensure the goodness of fit of the model, several measures were examined. The Root Mean Square Error of Approximation (RMSEA) of the model is 0.076, which indicates a good fit. The Normed Fit Index (NFI) is 0.85, the Non-Normed Fit Index (NNFI) is 0.89, the Incremental Fit Index (IFI) is 0.91, the Root Mean Square Residual (RMR) is 0.096, the Standardized RMR is 0.071 and the Goodness of Fit Index (GFI) is 0.83 , all of which indicate that the model is overall a good fit.

Based on Figure 7, product knowledge is reported to have a significant impact on perceived quality $(t$-values $=5.56 ; \mathrm{SLF}=0.52)$. Therefore, $H 1$ is supported. The study aligns with Blair and Innis's findings (1996) that the acquisition of knowledge supports the formation of perceived quality. In other words, Muslim customers who have more knowledge about Islamic bank term deposit products tend to have a more positive perception about the quality of the Islamic bank term deposit products.

Similar to H1, H2, which examines the impact of product knowledge on perceived risk, is supported ( $t$-values $=-3.32$; SLF $=-0.29)$. The study support the previous study conducted by Eisingerich and Bell (2008). The negative relationship between product knowledge and perceived risk shows that the Muslim customers who have lower information about the Islamic term deposit products tend to perceive them as higher in risk compared to the Muslim consumers who are more knowledgeable about them.

In contrast, the statistical results show that both $H 3$ and $H 4$ are rejected. The results indicate that product knowledge does not directly and significantly influence the value

\begin{tabular}{lccccc}
\hline Variable & Conventional only & Sharia only & Mixed & $F$-test & Sig \\
\hline Product knowledge & 2.9189 & 4.0283 & 3.9225 & 54.086 & $0.000^{*}$ \\
Perceived quality & 4.2200 & 4.4424 & 4.4930 & 2.584 & 0.078 \\
Perceived risk & 4.0929 & 3.7424 & 3.8509 & 1.258 & 0.286 \\
Perceived value & 4.0314 & 4.3939 & 4.3175 & 3.099 & $0.047^{*}$ \\
Intention to invest & 4.0171 & 4.3939 & 4.4509 & 3.424 & $0.034^{*}$ \\
\hline
\end{tabular}

Figure 7.

Hypothesis testing

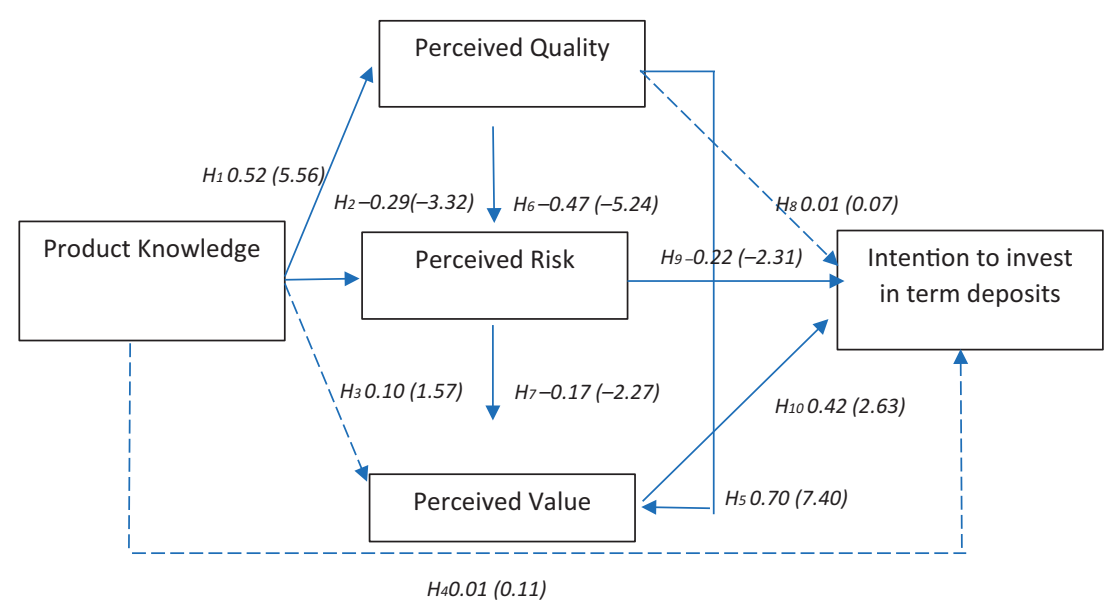


perception $(t$-values $=1.57$; SLF $=0.10)$ and intention of the customer $(t$-values $=-5.24$; $\mathrm{SLF}=-0.47$ ) to invest in Islamic bank term deposits.

H5 shows that perceived quality has a positive and significant effect on perceived value $(t$-values $=2.31 ; \mathrm{SLF}=0.22)$. The acceptance of $H 5$ is supported by previous studies, which reported that perceived quality is an essential component of perceived value (Dodds and Monroe, 1985; Ruiz et al., 2008). This indicates that the higher quality of the investment products and services from the Islamic bank, the higher the value perceived by customers.

However, customers will evaluate the perceived value to be lower if there is high perceived risk, which was indicated by the results of testing $H 6$ ( $t$-values $=2.31 ; \mathrm{SLF}=0.22$ ). The results for $H 6$ agree with the previous research by Snoj et al. (2004). Products that are perceived to have high quality will reduce the perceived risk in the eyes of the customers.

In addition, perceived risk is reported to have a negative and significant effect on perceived value $(t$-values $=-2.27$; SLF $=-0.17)$, as shown by the result of testing $H 7$. The results indicate that when Muslim customers perceive Islamic term deposits as high in risk, they tend to perceive the value of the product as low. This result agrees the study of Snoj et al. (2004).

Despite the significant impact of perceived quality on $H 5$ and $H 6$, the result of $H 8$ shows that perceived quality does not have a direct impact on the intention of Muslim customers to invest in Islamic bank term deposits $(t$-values $=0.07$; SLF $=0.01)$. However, perceived risk $(t$-values $=-2.31 ;$ SLF $=-0.22)$ and perceived value $(t$-values $=2.63 ;$ SLF $=0.42)$ are reported to have a significant impact on Muslim customers' intention to invest in Islamic bank term deposits. The $H 9$ test result supports the study of Croy et al. (2010), while the result of testing $\mathrm{H1O}$ is in line with research of Kuo et al. (2009).

The results of the above direct relationship hypotheses testing results can be summarized as shown in Table 4.

In addition to the previous hypothesis testing, which examined the direct effects of relationships, the indirect effects were assessed and calculated as can be seen in Table 5 .

As previous direct relationship between product knowledge is not significant on the intention to invest in Islamic term deposits. The indirect effect calculation, as shown in Table 5, shows that the impact of product knowledge on the Muslim consumers' intention to invest in Islamic term deposits is fully mediated via several alternative paths (path $\mathrm{f}, \mathrm{h}, \mathrm{i}$ and $\mathrm{j}$ in Table 5). Based on the value of the indirect effect of product knowledge on the intention to invest in Islamic bank term deposits, the highest impact of product knowledge is found via perceived risk (path $\mathrm{f}$ ) with an indirect effect of 0.064 .

\begin{tabular}{|c|c|c|c|c|c|}
\hline Hypotheses & Path & $t$-value & SLF & Results & \\
\hline$H 1$ & Product knowledge $\rightarrow$ Perceived quality & 5.56 & 0.52 & Supported & \\
\hline H2 & Product knowledge $\rightarrow$ Perceived risk & -3.32 & -0.29 & Supported & \\
\hline H3 & Product knowledge $\rightarrow$ Perceived value & 1.57 & 0.10 & Not Supported & \\
\hline H4 & Product knowledge $\rightarrow$ Intention to invest & 0.11 & 0.01 & Not Supported & \\
\hline H5 & Perceived quality $\rightarrow$ Perceived value & 2.31 & 0.22 & Supported & \\
\hline H6 & Perceived quality $\rightarrow$ Perceived risk & -5.24 & -0.47 & Supported & \\
\hline$H 7$ & Perceived risk $\rightarrow$ Perceived value & -2.27 & -0.17 & Supported & \\
\hline H8 & Perceived quality $\rightarrow$ Intention to invest & -0.07 & -0.01 & Not Supported & \\
\hline H9 & Perceived risk $\rightarrow$ Intention to invest & -2.31 & -0.22 & Supported & Table 4. \\
\hline H1O & Perceived value $\rightarrow$ Intention to invest & 2.63 & 0.42 & Supported & Direct effects \\
\hline
\end{tabular}




\section{JIMA \\ 12,7}

\begin{tabular}{|c|c|c|c|}
\hline & Path & Calculations & Indirect effects \\
\hline a & $\begin{array}{l}\text { Product knowledge } \rightarrow \text { Perceived quality } \rightarrow \\
\text { Perceived risk }\end{array}$ & $0.52 \times-0.47$ & -0.244 \\
\hline b. & $\begin{array}{l}\text { Product knowledge } \rightarrow \text { Perceived quality } \rightarrow \\
\text { Perceived value }\end{array}$ & $0.52 \times 0.22$ & 0.114 \\
\hline c. & $\begin{array}{l}\text { Product knowledge } \rightarrow \text { Perceived quality } \rightarrow \\
\text { Perceived risk } \rightarrow \text { Perceived value }\end{array}$ & $0.52 \times-0.47 \times-0.17$ & 0.000 \\
\hline d. & $\begin{array}{l}\text { Product knowledge } \rightarrow \text { Perceived risk } \rightarrow \\
\text { Perceived value }\end{array}$ & $-0.29 \times-0.17$ & 0.049 \\
\hline e. & $\begin{array}{l}\text { Product knowledge } \rightarrow \text { Perceived quality } \rightarrow \\
\text { Intention to invest }\end{array}$ & $0.52 \times-0.01$ & $-0.005^{*}$ \\
\hline f. & $\begin{array}{l}\text { Product knowledge } \rightarrow \text { Perceived risk } \rightarrow \\
\text { Intention to invest }\end{array}$ & $-0.29 \times-0.22$ & 0.064 \\
\hline g. & $\begin{array}{l}\text { Product knowledge } \rightarrow \text { Perceived value } \rightarrow \\
\text { Intention to invest }\end{array}$ & $0.1 \times 0.42$ & $0.042 *$ \\
\hline h. & $\begin{array}{l}\text { Product knowledge } \rightarrow \text { Perceived quality } \rightarrow \\
\text { Perceived risk } \rightarrow \text { Intention to invest }\end{array}$ & $0.52 \times-0.47 \times-0.22$ & 0.054 \\
\hline i. & $\begin{array}{l}\text { Product knowledge } \rightarrow \text { Perceived quality } \rightarrow \\
\text { Perceived value } \rightarrow \text { Intention to invest }\end{array}$ & $0.52 \times 0.22 \times 0.42$ & 0.048 \\
\hline j. & $\begin{array}{l}\text { Product knowledge } \rightarrow \text { Perceived quality } \rightarrow \\
\text { Perceived risk } \rightarrow \text { Perceived value } \rightarrow \\
\text { Intention to invest }\end{array}$ & $0.52 \times-0.47 \times-0.17 \times 0.42$ & 0.017 \\
\hline
\end{tabular}

Table 5.

Note: *Insignificant path

\section{Discussion}

This study examines the impact of product knowledge on purchase intention via the mediation of perceived quality, perceived financial risk and perceived value. The result shows that product knowledge has no direct influence on customers' intention to save in Islamic bank term deposits. The result implies that getting enough information about the Islamic bank term deposits product itself is not sufficient to attract customers to invest in Islamic bank term deposit but mediated by perceived quality and perceived risk.

Product knowledge has a significant influence on customers' intention to invest in Islamic bank term deposits via two routes. The first of these is via perceived quality, and the second is simultaneously via perceived quality and perceived risk because perceived quality has a significant influence on perceived risk but no significant impact on saving intention.

Both routes show that perceived risk may have two roles in influencing Muslim customers' intention to invest in Islamic banks. The first role is as an independent variable that directly influences Muslim customers' intention to invest in Islamic banks. The second role is as an intervening variable that mediates the relationship between product knowledge and intention to invest in Islamic bank term deposits and between perceived quality and intention.

Thus, this study theoretically contributes to the current research in Islamic marketing by providing empirical evidence that customers' product knowledge cannot work alone in influencing Muslims' intention to invest in term deposits without the involvement of two mediating variables: product quality and perceived risk.

\section{Managerial implications, limitation and future research}

The central role of perceived risk in influencing Muslim customers' intention to invest in Islamic term deposit products highlights some managerial implications of the study for 
Islamic banks. First, as the perceived risk is negatively influenced by product knowledge, customer education that provides details and comprehensive information regarding the risks inherent in term deposit products needs to be conducted. As explained earlier, the study was conducted in Indonesia, where sharing of Islamic banking returns is performed based on the revenue sharing concept rather than the PLS concept (Ismal, 2012). Thus, the investors are free from any obligation to bear risk. As a consequence, Islamic bank customers can always be expected to receive a positive and regular return (Ismal, 2012). The complexities of the Islamic bank financial products and the absence of risk in its term deposit products requires the Islamic bank to inform the depositors about the application of the revenue sharing concept instead of the profit loss sharing concept. The information is needed since the Muslim customers' cognitive, affective and conative decision-making patterns are also affected by risk minimization (Wilson and Liu, 2011). Otherwise, the customers will perceive that the investment product in the Islamic bank truly applies the PLS concept, which is much riskier and low in value than the investment in conventional banks. This information can be regularly disseminated to customers through many types of marketing communication channels such as advertising, social media and personal selling.

Second, because an additional analysis shows a different level of product knowledge, perceived quality, perceived risk and perceived value among different types of account holders, the Islamic banks should conduct more customized marketing programs to target each market segment such that the bank will have a more effective marketing program. This issue has been raised by a previous study because the product knowledge of the consumer has a changing nature over time (Bell and Eisingerich, 2007).

Third, Islam is built on the foundation of wisdom and people's welfare in this world and the afterlife (Maqasid al-Shariah). Since the Muslim inhabitants in Indonesia believe in life after death, they will evaluate and consider actions and benefits beyond death (Wilson and Hollensen, 2013). Moreover, Muslim customers are not only keen to partake in global consumer culture but also try to remain faithful to their Islamic values (Wilson et al., 2013). Thus, the managers of Islamic banks should put more effort into educating the customers not only about the quality, risk and value of the Islamic bank term deposit products but also how the products satisfy their needs and wants in present and afterlife.

One limitation of this research is that it only focuses on one type of Islamic bank investment product (term deposit). Some exploration on the impact of customer product knowledge and perception on Muslim customers' intention to invest in other types of Islamic bank products would be considerably beneficial for the Islamic finance and marketing literature. In addition, the research was conducted in a context where the revenue sharing concept is applied rather than the ideal PLS concept. Future studies should examine the role of product knowledge in influencing customer perception of risk, value, quality and investment intention in the context of products that fully apply the ideal PLS concept.

\section{References}

"Maqasid al-Shari'ah" (2020), "Islamic-Banking.Com”, 16 April, available at: www.Islamic-banking. com/moral-oath/maqasid-al-shariah (accessed 16 April 2020).

"Muslim Population By Country" (2020), available at: https://worldpopulationreview.com/countries/ Muslim-population-by-country/ (accessed 21 April 2020).

Agarwal, S. and Teas, R.K. (2001), "Perceived value: mediating role of perceived risk", Journal of Marketing Theory and Practice, Vol. 9 No. 4, pp. 1-14.

Aghekyan-Simonian, M., Forsythe, S., Suk Kwon, W. and Chattaraman, V. (2012), "The role of product Brand image and online store image on perceived risks and online purchase intentions for 
JIMA

12,7

1380 apparel”, Journal of Retailing and Consumer Services, Vol. 19 No. 3, pp. 325-331, doi: 10.1016/j. jretconser.2012.03.006.

Ahmad, K. (2016), "Islamic finance and banking: the challenge and prospects, review of Islamic economics".

Ahmad, N. and Haron, S. (2002), "Perceptions of Malaysian corporate customers towards Islamic banking products and services", International Journal of Islamic Financial Services, Vol. 3 No. 4, pp. 13-29.

Akram, N. and Akram, M.I. (2015), "Savings behaviour in Muslim and non-Muslim countries in context to the interest rate", Pakistan Journal of Applied Economics, Vol. 25 No. 2, pp. 161-177.

Alba, J.W. and Hutchinson, J.W. (1987), "Dimensions of consumer expertise", Journal of Consumer Research, Vol. 13 No. 4, p. 411.

Ali, F., Omar, R. and Amin, M. (2013), "An examination of the relationships between physical environment, perceived value, image and behavioural intentions: a SEM approach towards Malaysian resort hotels", Journal of Hotel and Tourism Management, Vol. 27 No. 2, pp. 9-26.

Amin, H. (2013), "Some viewpoints of Islamic banking retail deposit products in Malaysia", Journal of Internet Banking and Commerce, Vol. 18 No. 2, p. 1.

Amin, H., Rahim Abdul Rahman, A., Laison Sondoh, S. and Magdalene Chooi Hwa, A. (2011), "Determinants of customers' intention to use Islamic personal financing: the case of Malaysian Islamic banks", Journal of Islamic Accounting and Business Research, Vol. 2 No. 1, pp. $22-42$.

Ando, A. and Modigliani, F. (1963), "The 'life cycle' hypothesis of saving: aggregate implications and tests", The American Economic Review, Vol. 53 No. 1, pp. 55-84.

Bacon, D.R., Sauer, P.L. and Young, M. (1995), "Composite reliability in structural equations modeling”, Educational and Psychological Measurement, Vol. 55 No. 3, pp. 394-406, doi: 10.1177/ 0013164495055003003.

Bamber, D. Phadke, S. and Jyothishi, A. (2012), "Product-knowledge, ethnocentrism and purchase intention: COO study in India", NMIMS Management Review.

Bank Indonesia (2018), "Posisi Simpanan Masyarakat Pada Bank Umum Dan BPR Menurut Kelompok Bank".

Bankbazaar.com (2018), "Term deposit: what is it and how it works", available at: www.bankbazaar. com/fixed-deposit/term-deposit.html?ck=Y\%2BziX71XnZjIM9ZwEflsyGctlVzARfJL1SHGG10 VFxSZC0TqFEkhF6ljN6nbC1ZXXBwImSfaF7\%2BS\%0AmJOG7qYyyg \%3D\%3D\&rc=1 (accessed 11 September 2018).

Bell, S.J. and Eisingerich, A.B. (2007), "The paradox of customer education: customer expertise and loyalty in the financial services industry", European Journal of Marketing, Vol. 41 Nos 5/6, pp. 466-486, doi: 10.1108/03090560710737561.

Blair, M.E. and Innis, D.E. (1996), "The effects of product knowledge on the evaluation of warranteed brands", Psychology and Marketing, Vol. 13 No. 5, pp. 445-456, doi: 10.1002/(SICI)1520-6793 (199608)13:5<445::AID-MAR1>3.3.CO;2-P.

Bloemer, J., de Ruyter, K. and Peeters, P. (1998), "Investigating drivers of bank loyalty: the complex relationship between image, service quality and satisfaction", International Journal of Bank Marketing, Vol. 16 No. 7, pp. 276-286, doi: 10.1108/02652329810245984.

Bloomberg (2019), "Biggest Indonesian Islamic bank sees sector riding on a wave of halal lifestyle", available at: https://themalaysianreserve.com/2019/02/07/biggest-indonesian-Islamic-bank-seessector-riding-on-a-wave-of-halal-lifestyle/ (accessed 21 April 2020).

Cakici, N.M. and Shukla, P. (2017), "Country-of-origin misclassification awareness and consumers' behavioral intentions", International Marketing Review, Vol. 34 No. 3, pp. 354-376, doi: 10.1108/ IMR-08-2015-0178.

Chapra, M.U., Khan, S. and Shaikh-Ali, A.A. (2008), The Islamic Vision of Development in the Light of Maqasid Al-Shariah, IIIT. 
Chen, T.Y. and Chang, H.S. (2005), "Reducing consumers' perceived risk through banking service quality cues in Taiwan", Journal of Business and Psychology, Vol. 19 No. 4, pp. 521-540.

Chiang, C.-C. and Lee, L.-Y. (2013), "An examination of perceived value dimensions of hotel visitors: using exploratory and confirmatory factor analyses", Journal of International Management Studies.

Chong, B.S. and Liu, M.H. (2009), "Islamic banking: interest-free or interest-based?", Pacific Basin Finance Journal, Vol. 17 No. 1, pp. 125-144, doi: 10.1016/j.pacfin.2007.12.003.

Clow, K., Baack, D. and Fogliasso, C. (1998), "Reducing perceived risk through advertising service quality

Croy, G., Gerrans, P. and Speelman, C. (2010), "The role and relevance of domain knowledge, perceptions of planning importance, and risk tolerance in predicting savings intentions", Journal of Economic Psychology, Vol. 31 No. 6, pp. 860-871.

Das, G. (2015), "Linkages between self-congruity, brand familiarity, perceived quality and purchase intention: a study of fashion retail brands", Journal of Global Fashion Marketing, Vol. 6 No. 3, pp. 180-193.

Devlin, J.F. (2002), "Customer knowledge and choice criteria in retail banking”, Journal of Strategic Marketing, Vol. 10 No. 4, pp. 273-290, doi: 10.1080/0965254022000014541.

Diamant, J. (2019), "The countries with the 10 largest Christian populations and the 10 largest Muslim populations", Pew Research Center, available at: www.pewresearch.org/fact-tank/2019/04/01/thecountries-with-the-10-largest-christian-populations-and-the-10-largest-Muslim-populations/ (accessed 21 April 2020).

Dodds, W.B. and Monroe, K.B. (1985), "The effect of brand and price information on subjective product evaluations", Advances in Consumer Research, Vol. 12 No. 1, pp. 85-90, doi: 10.1037/a0026025.

Dusuki, A.W. and Abdullah, N.I. (2007), "Why do Malaysian customers patronise Islamic banks?", International Journal of Bank Marketing, Vol. 25 No. 3, pp. 142-160, doi: 10.1108/02652320710739850.

Dusuki, A.W. and Abozaid, A. (2007), "A critical appraisal on the challenges of realizing Maqasid AlShariaah in Islamic banking and finance", International Journal of Economics, Management and Accounting, Vol. 15 No. 2, pp. 143-165, available at: https://journals.iium.edu.my/enmjournal/ index.php/enmj/article/view/133 (accessed 16 April 2020).

Echchabi, A. and Olaniyi, O.N. (2012), "Using theory of reasoned action to model the patronisation behaviour of Islamic banks' customers in Malaysia”, Research Journal of Business Management, Vol. 6 No. 3, pp. 70-82, doi: 10.3923/rjbm.2012.70.82.

Eisingerich, A.B. and Bell, S.J. (2008), "Perceived service quality and customer trust: does enhancing customers' service knowledge matter?", Journal of Service Research, Vol. 10 No. 3, pp. 256-268, doi: 10.1177/1094670507310769.

Epstein, J., Klinkenberg, W.D., Wiley, D. and McKinley, L. (2001), "Insuring sample equivalence across internet and paper-and-pencil assessments", Computers in Human Behavior, Vol. 17 No. 3, pp. 339-346, doi: 10.1016/S0747-5632(01)00002-4.

Erol, C. and El-Bdour, R. (1989), "Attitudes, behavior and patronage factors of bank customers towards Islamic banks", International Journal of Bank Marketing, Vol. 7 No. 6, pp. 31-37.

Friedman, M. (1957), A Theory of the Consumption Function, Princeton University Press, Princeton, NJ.

Gray, A. (2018), "Bank competition heats up for US customer deposits", Financial Times, available at: www.ft.com/content/846ebaa0-38fd-11e8-8b98-2f31af407cc8 (accessed 11 September 2018).

Grewal, D., Gotlieb, J. and Marmorstein, H. (1994), "The moderating effects of message framing and source credibility on the price-perceived risk relationship", Journal of Consumer Research, Vol. 21 No. 1, pp. 145-153, doi: 10.1086/209388.

Hair, J.F., Matthews, L.M., Matthews, R.L. and Sarstedt, M. (2017), "PLS-SEM or CB-SEM: updated guidelines on which method to use", International Journal of Multivariate Data Analysis, Vol. 1 No. 2, pp. 107-123, doi: 10.1504/IJMDA.2017.087624. 
Hamzah, A.A., Ruzaiman, F.S. and Gazali, H.M. (2014), "Islamic investment deposit account through Mudarabah and commodity Murabahah contract: an overview", Persidangan Kebangsaan Ekonomi Malaysia Ke-9 (PERKEM), Vol. 9, pp. 28-33.

Haron, S. and Ahmad, N. (2000), "The effects of conventional interest rates and rate of profit on funds deposited with Islamic banking system in Malaysia", International Journal of Islamic Financial Services, Vol. 1 No. 4, pp. 1-7.

Haron, S., Ahmad, N. and Planisek, S.L. (1994), "Bank patronage factors of Muslim and non-Muslim customers", International Journal of Bank Marketing, Vol. 12 No. 1, pp. 32-40.

Hilman, I. (2016), "The factor affecting Mudharabah deposits of Sharia banking in Indonesia", International Journal of Business and Management Invention, doi: 10.21511/bbs.11(3).2016.03.

Hossain, M.Z. (2009), "Why is interest prohibited in Islam? A statistical justification”, Humanomics, Vol. 25 No. 4, pp. 241-253, doi: 10.1108/08288660910997610.

Indonesia Financial Service Authority (2018), "Statistik Perbankan Syariah - Juni 2018", available at: www.ojk.go.id/id/kanal/syariah/data-dan-statistik/statistik-perbankan-syariah/Pages/StatistikPerbankan-Syariah-Juni-2018.aspx (accessed 12 September 2018).

Iqbal, M. and Molyneux, P. (2005), Thirty Years of Islamic Banking: History, Performance and Prospects, Thirty Years of Islamic Banking; History, Performance and Prospects, Springer, doi: 10.1057/9780230503229.

Ismal, R. (2012), "Formulating withdrawal risk and bankruptcy risk in Islamic banking", International Journal of Islamic and Middle Eastern Finance and Management, Vol. 5 No. 1, pp. 63-77, doi: $10.1108 / 17538391211216848$.

Jayani, D.H. (2019), “Juni 2019, Dana Pihak Ketiga Tumbuh 7,4\%", available at: https://databoks. katadata.co.id/datapublish/2019/08/26/juni-2019-dana-pihak-ketiga-tumbuh-74 (accessed 21 April 2020).

Kasri, R.A. and Kassim, S.H. (2009), "Empirical determinants of saving in the Islamic banks: evidence from Indonesia", Journal of King Abdulaziz University, Islamic Economics, Vol. 22 No. 2, doi: 10.2139/ssrn.1685226.

Kuo, Y.F., Wu, C.M. and Deng, W.J. (2009), "The relationships among service quality, perceived value, customer satisfaction, and post-purchase intention in mobile value-added services", Computers in Human Behavior, Vol. 25 No. 4, pp. 887-896, doi: 10.1016/j.chb.2009.03.003.

Kwun, J.-W. and Oh, H. (2004), "Effects of brand, price, and risk on customers' value perceptions and behavioral intentions in the restaurant industry", Journal of Hospitality and Leisure Marketing, Vol. 11 No. 1, doi: 10.1300/J150v11n01_03.

Laroche, M., Bergeron, J. and Goutaland, C. (2003), "How intangibility affects perceived risk: the moderating role of knowledge and involvement”, Journal of Services Marketing, Vol. 17 No. 2, doi: $10.1108 / 08876040310467907$.

Lin, L.Y. and Chen, C.S. (2006), "The influence of the country-of-origin image, product knowledge and product involvement on consumer purchase decisions: an empirical study of insurance and catering services in Taiwan”, Journal of Consumer Marketing, Vol. 23 No. 5, doi: 10.1108/ 07363760610681655 .

Livepopulation.com (2018), "Population of Indonesia 2018”, Population of the World, available at: www. livepopulation.com/country/indonesia.html (accessed 12 September 2018).

Meera, A.K.M. and Larbani, M. (2006), "Part I: Seigniorage of fiat money and the Maqasid Al-Shari'ah: the unattainableness of the Maqasid", Humanomics, Vol. 22 No. 1, pp. 17-33.

Mehrotra, S. and Palmer, J. (1985), "Relating product features to perceptions of quality: appliances", Perceived Quality, Lexington Books, Toronto, pp. 81-96.

Mushtaq, S. and Siddiqui, D.A. (2016), "Effect of interest rate on economic performance: evidence from Islamic and non-Islamic economies", Financial Innovation, Vol. 2 No. 1, doi: 10.1186/s40854-0160028-7. 
Mylonakis, J., Malliaris, P.G. and Siomkos, G.J. (1998), "Marketing-driven factors influencing savers in the Hellenic bank market", Journal of Applied Business Research (JABR), Vol. 14 No. 2, pp. 109-116.

Nepomuceno, M.V., Laroche, M. and Richard, M.-O. (2014), "How to reduce perceived risk when buying online: the interactions between intangibility, product knowledge, brand familiarity, privacy and security concerns", Journal of Retailing and Consumer Services, Vol. 21 No. 4, pp. 619-629.

Newaz, F.T., Fam, K.S. and Sharma, R.R. (2016), "Muslim religiosity and purchase intention of different categories of Islamic financial products", Journal of Financial Services Marketing, Vol. 21 No. 2, doi: $10.1057 / \mathrm{fsm} .2016 .7$.

Ophuis, P.A.M.O. and Van Trijp, H.C.M. (1995), "Perceived quality: a market driven and consumer oriented approach", Food Quality and Preference, Vol. 6 No. 3, pp. 177-183.

Parasuraman, A. and Grewal, D. (2000), “The impact of technology on the quality-value-loyalty chain: a research agenda", Journal of the Academy of Marketing Science, Vol. 28 No. 1, doi: 10.1177/ 0092070300281015.

Park, C.W. and Lessig, V.P. (1981), "Familiarity and its impact on consumer decision biases and heuristics", Journal of Consumer Research, Vol. 8 No. 2, pp. 223-231.

Pramono, S. (2018), "Analysis of slow paced market penetration of Indonesia's Islamic banking: an Islamic bank rent perspective", available at: https:/Islamicmarkets.com/publications/analysisof-slow-paced-market-penetration-of-indonesia-s-Islamic-banking (accessed 21 April 2020).

Rao, A.R. and Monroe, K.B. (1988), "The moderating effect of prior knowledge on cue utilization in product evaluations", Journal of Consumer Research, Vol. 15 No. 2, doi: 10.1086/209162.

Reichheld, F.F. and Sasser, W.E. (1990), "Zero defections: quality comes to services”, Harvard Business Review, doi: 10.1016/j.colsurfa.2006.11.029.

Roig, J.C.F., Garcia, J.S., Tena, M.A.M. and Monzonis, J.L. (2006), "Customer perceived value in banking services", International Journal of Bank Marketing, Vol. 24 No. 5, pp. 266-283.

Rosly, S.A. and Zaini, A.M. (2008), "Risk-return analysis of Islamic banks' investment deposits and shareholders' fund", Managerial Finance, Vol. 34 No. 10, pp. 695-707, doi: 10.1108/ 03074350810891010.

Ruiz, D.M., Gremler, D.D., Washburn, J.H. and Carrión, G.C. (2008), "Service value revisited: specifying a higher-order, formative measure”, Journal of Business Research, Vol. 61 No. 12, doi: 10.1016/j. jbusres.2008.01.015.

Setyobudi, W.T., Wiryono, S.K., Nasution, R.A. and Purwanegara, M.S. (2015), "Exploring implicit and explicit attitude toward saving at Islamic bank", Journal of Islamic Marketing, Vol. 6 No. 3, doi: 10.1108/JIMA-08-2014-0055.

Snoj, B., Pisnik Korda, A. and Mumel, D. (2004), "The relationships among perceived quality, perceived risk and perceived product value", Journal of Product and Brand Management, Vol. 13 No. 3, doi: 10.1108/10610420410538050.

Stone, R.N. and Grønhaug, K. (1993), "Perceived risk: further considerations for the marketing discipline", European Journal of Marketing, Vol. 27 No. 3, pp. 39-50.

Sweeney, J.C., Soutar, G.N. and Johnson, L.W. (1999), "The role of perceived risk in the quality-value relationship: a study in a retail environment", Journal of Retailing, Vol. 75 No. 1, doi: 10.1016/ S0022-4359(99)80005-0.

Thambiah, S., Cyril Eze, U., Santhapparaj, A.J. and Arumugam, K. (2010), “Customers' perception on Islamic retail banking: a comparative analysis between the urban and rural regions of Malaysia", International Journal of Business and Management, Vol. 6 No. 1, doi: 10.5539/ijbm. v6n1p187.

Ting, H., Lau, W.M., Cheah, J.H., Yacob, Y., Memon, M.A. and Lau, E. (2018), "Perceived quality and intention to revisit coffee concept shops in Malaysia: a mixed-methods approach", British Food Journal, Vol. 120 No. 5, doi: 10.1108/BFJ-08-2017-0452. 
JIMA

12,7

1384

Wang, E.S.-T. (2017), "Different effects of utilitarian and hedonic benefits of retail food packaging on perceived product quality and purchase intention", Journal of Food Products Marketing, Vol. 23 No. 3, pp. 239-250.

Wang, Q. Dacko, S. and Gad, M. (2008), "Factors influencing consumers' evaluation and adoption intention of really - new products or services: prior knowledge, innovativeness and timing of product evaluation", Advances in Consumer Research.

Wang, Y. and Hazen, B.T. (2016), "Consumer product knowledge and intention to purchase remanufactured products", International Journal of Production Economics, Vol. 181, doi: 10.1016/ j.ijpe.2015.08.031.

Wang, Y., Wiegerinck, V., Krikke, H. and Zhang, H. (2013), "Understanding the purchase intention towards remanufactured product in closed-loop supply chains: an empirical study in China", International Journal of Physical Distribution and Logistics Management, Vol. 43 No. 10, pp. 866-888, doi: 10.1108/IJPDLM-01-2013-0011.

Warde, I. (2000), Islamic Finance in the Global Economy, Edinburgh University Press, Edinburgh.

Wilson, J.A., Belk, R.W., Bamossy, G.J., Sandikci, Ö., Kartajaya, H., Sobh, R., Liu, J. and Scott, L. (2013), "Crescent marketing, Muslim geographies and brand Islam: reflections from the JIMA senior advisory board", Journal of Islamic Marketing, Vol. 4 No. 1, pp. 22-50.

Wilson, J.A.J. and Hollensen, S. (2013), “Assessing the implications on performance when aligning customer lifetime value calculations with religious faith groups and after lifetime values - a Socratic Elenchus approach", International Journal of Business Performance Management, Vol. 14 No. 1, p. 67.

Wilson, J.A.J. and Liu, J. (2011), "The challenges of Islamic branding: navigating emotions and halal", Journal of Islamic Marketing, Vol. 2 No. 1, pp. 28-42.

Žabkar, V., Brenčič, M.M. and Dmitrović, T. (2010), "Modelling perceived quality, visitor satisfaction and behavioural intentions at the destination level", Tourism Management, Vol. 31 No. 4, pp. 537-546.

Zeithaml, V.A. (1988), “Consumer perceptions of price, quality, and value: a means-end model and synthesis of evidence", Journal of Marketing, Vol. 52 No. 3, p. 2.

Corresponding author

Sri Rahayu Hijrah Hati can be contacted at: sri.rahayu72@ui.ac.id

For instructions on how to order reprints of this article, please visit our website:

www.emeraldgrouppublishing.com/licensing/reprints.htm

Or contact us for further details: permissions@emeraldinsight.com 